\title{
Effect of Cognitive Behavior Therapy (CBT) Intervention on Serum Cortisol Level and Pain Score of Patients with Advanced- Stage Cervical Cancer
}

\author{
Soetrisno*, Sri Sulistyowati, Supriyadi Hari Respati, Rizka Pramudhita \\ Department of Obstetric and Gynecology, Faculty of Medicine, Sebelas Maret University, \\ Dr. Moewardi Hospital, Surakarta
}

DOI: http://dx.doi.org/10.19106/JMedSci004803201603

\begin{abstract}
Cervical cancer is the most frequent cause of death related gynecology malignancy in Indonesia. Recent management of advanced-stage cervical cancer has still not been able to improve the prognosis. Chemotherapy and radiation intervention, as well as therapy may resulting pain and cause psychological stress for some patient, furthermore it could effect on the quality of life. Cortisol is a hormone of adrenal cortex, it secretes due to increased production of $\mathrm{ACTH}$ by anterior pituitary which is associated with stressful condition.

To analyze the effect of Cognitive Behavior Therapy (CBT) intervention on serum cortisol levels and pain score of patients with advanced-stage cervical cancer.

This experimental study was a double blind non-randomized clinical trial post-test group design. It was using two groups in this study, each group consisting of 15 subjects, the treatment group were given CBT and standard therapy, while the control group were only given a standard therapy. The study was conducted in the gynecology oncology ward and the gynecology oncology clinic of Dr. Moewardi Hospital Surakarta and Prodia Laboratory, from January - March 2015. Cortisol level of the treatment group was 1.03 $\pm 0.71 \mathrm{mg} / \mathrm{dL}$, and the control group was $11.41 \pm 7.34 \mathrm{mg} / \mathrm{dL}$. Pain score in the treatment group was $4.46 \pm 0.83$, and the control group was $7.34 \pm 0.74$.

There are significant differences in serum cortisol level decrease $(p=0.00)$ and pain score $(p=0.00)$ between the CBT intervention with standard therapy group compared and the standard therapy only group.
\end{abstract}

\section{ABSTRAK}

Kanker serviks merupakan penyebab kematian tersering yang berhubungan dengan keganasan ginekologi di Indonesia. Manajemen terbaru untuk kanker serviks stadium lanjut masih belum mampu meningkatkan prognosis. Kemoterapi, intervensi radiasi, dan terapi dapat mengakibatkan rasa sakit serta menyebabkan stres psikologis untuk beberapa pasien, selanjutnya dapat berpengaruh pada kualitas hidup. Kortisol adalah hormon korteks adrenal, hormon ini disekresikan karena peningkatan produksi ACTH oleh hipofisis anterior yang berhubungan dengan kondisi stres. Cognitive Behavioral Theraphy (CBT) diharapkan dapat menurunkan stres dan mengurangi nyeri pada pasien kanker servik stadium lanjut sehingga berdampak positif meningkatkan kualitas hidupnya. Tujuan penelitian untuk

$\overline{\text { Corresponding author: soetrisno_spogk@yahoo.com }}$ 
menganalisis pengaruh intervensi Cognitive Behavior Therapy (CBT) terhadap tingkat kortisol serum dan skor nyeri pasien dengan kanker serviks stadium lanjut.

Penelitian eksperimental ini adalah uji klinis non-randomized double blind post-test only group desain. Penelitian ini menggunakan dua kelompok yaitu kelompok perlakuan diberi CBT dan terapi standar, dan kelompok kontrol diberi terapi standar, masing-masing kelompok terdiri dari 15 orang. Penelitian dilakukan di bangsal ginekologi onkologi dan klinik ginekologi onkologi Rumah Sakit Dr. Moewardi Surakarta, serta Laboratorium Prodia, dari bulan Januari-Maret 2015. Hasil menunjukkan bahwa tingkat kortisol kelompok perlakuan adalah $1,03 \pm 0,71 \mathrm{mg} / \mathrm{dL}(\mathrm{p}=0.00)$, dan kelompok kontrol adalah 11,41 $\pm 7.34 \mathrm{mg} / \mathrm{dL}$. Skor nyeri pada kelompok perlakuan adalah $4,46 \pm 0,83$, dan kelompok kontrol adalah 7,34 $\pm 0,74(p=0.00)$. Sebagai kesimpulan adalah ada perbedaan yang signifikan dalam penurunan tingkat kortisol serum dan skor nyeri antara kelompok intervensi dan kelompok kontrol.

Keywords: Cortisol, pain scores, CBT, standard therapy, advanced cervical cancer

\section{INTRODUCTION}

Cervical cancer is the most frequent cause of death related gynecology malignancy, and second place after breast cancer in female. Five hundred thousand new cases of cervical cancer occured all around worldwide each year, with a mortality incidence is over 250,000 cases. World Health Organization (WHO) estimates that cervical cancer death-related will increase to $25 \%$ for the next 10 years. In Indonesia, which has population approximately 220 million people, it is estimated there are more than 52 million women who are threatened acquiring cervical cancer. ${ }^{1}$

The immune system in cervical cancer plays an important role to fight the cancer cell, the protective function is going through the process of recognition and destruction of abnormal cells before they become tumor cells, but in cancer patient, often occured an immune suppression, so the tumor cell will grow rapidly. ${ }^{2}$ Recent management of advanced-stage cervical cancer has still not been able to improve the prognosis. Multiple platinum-based therapy with hematopoietic supportive therapy has been developed, but the results are still not satisfying and end up with the problem of drug resistance. Immunology treatment, whether as a single therapy or a combination with surgery, neither chemotherapy nor radiation aimed to gain specic-immunity against tumor cell, its also give not an effective result. ${ }^{3}$ The last few years some researcher was developing psychotherapy, including logotherapy, Cognitive Behavior Therapy (CBT), and reality therapy. ${ }^{4}$ Advanced-stage cervical cancer patients often suffer stress physically, emotionally and socially, furthermore its continue into depressive. ${ }^{5}$

Pain often appears in patient with cancer, and usually as a direct result of the tumor (75-80\% of cases) and the others caused either due to an anticancer treatment (15$19) \%$ ) or the pain unrelated to cancer or its treatment $(3-5 \%)$. Patient with cancer-pain may experience an acute pain, intermittent, or chronic at various stages of the disease. Most of them that associated with cancer-pain is a chronic pain. ${ }^{6}$ Psychotherapy CBT is expected to reduce stress and relieve the pain so that the positive impact on the livelihood could be improved along with the increasing quality of life and the five year survival rate in patient. ${ }^{4}$ Positive relationship psychotherapy CBT for 
patient with advanced cervical cancer has yet to be explained, in particular biomolecular. This study aimed to explain in biomolecular field, particularly decreasing in serum cortisol level in addition to pain score of advancedstage cervical cancer patients who have received CBT.

\section{METHOD}

This study was using an experimental non randomized double blind clinical trial post-test group design. Subjects of the study are patients with advanced-stage cervical cancer (II B- IV) selected by simple random sampling, which met the inclusion criteria; can communicate well in Bahasa, minimum education was Elementary School, signing an informed consent and for exclusion criteria; accompanied by another cancer, pregnancy, psychotic and depression history of previous treatment. This study was using two groups, each group consisted of 15 subjects. The treatment group was given CBT with standard therapy, while the control is only given standard therapy. The treatment is done by a competent psychiatrist. The independent variable is CBT, dependent variable is serum cortisol level and pain score according to Wong Baker Faces Pain Scale. The study was conducted in the gynecology oncology ward and the gynecology oncology polyclinic of Dr. Moewardi Hospital Surakarta and Prodia Laboratory, from January-March 2015, after obtaining an approval from the faculty of medicine ethical committee. Data were collected, tested statistically using the T Test by using SPSS for windows version 17.00

TABLE 1. Subject Characteristic Data

\begin{tabular}{llcc}
\hline Variable & Category & Total & $\%$ \\
\hline Age & $\leq 40$ years & 2 & 6.7 \\
& $>40$ years & 28 & 93.3 \\
Work status & Workng & 21 & 70 \\
& Housewife & 9 & 30 \\
Education & Elementary & 7 & 23.3 \\
& Junior High & 10 & 33.3 \\
& High School & 13 & 43.4 \\
Parity & Primi & 3 & 10 \\
& Sekundi & 12 & 40 \\
& Multi & 15 & 50 \\
\hline
\end{tabular}

In TABLE 1, it appears that the majority of patients aged $>40$ years is 28 cases $(93.3 \%)$, working patient is in 21 cases $(70 \%)$, with high school educational background is 13 cases (43.4\%) and 15 cases of multigravida $(50 \%)$.

TABLE 2. Bivariate Analysis of Research Subject Characteristics

\begin{tabular}{llccccc}
\hline Variable & Category & Treatment & $\%$ & Control & $\%$ & $\mathrm{p}$ \\
\hline Age & $\leq 40$ years & 0 & 0 & 2 & 13.3 & 0.14 \\
& $>$ 40 years & 15 & 100 & 13 & 86.7 & \\
Employment & Working & 10 & 66.7 & 11 & 73.3 & 0.69 \\
& Housewife & 5 & 33.3 & 4 & 26.7 & \\
Educational & Elementary & 2 & 13.3 & 5 & 33.3 & 0.16 \\
& Junior High & 4 & 26.7 & 6 & 40.0 & \\
\multirow{5}{*}{ Parity } & High School & 9 & 60.0 & 4 & 26.7 & \\
& Primi & 0 & 0 & 3 & 20.0 & 0.11 \\
& Sekundi & 8 & 53.3 & 4 & 26.7 & \\
& Multi & 7 & 46.7 & 7 & 53.3 & \\
\hline
\end{tabular}


In TABLE 2, it appears that there are no significant differences in maternal age, employment, education and parity in both groups $(\mathrm{p}>0.05)$.

TABLE 3. Cortisol level in normality test result (Kolmogorov-Smirnov) between treatment and control group.

\begin{tabular}{lcc}
\hline Group & $\mathrm{N}$ & $\mathrm{P}$ \\
\hline Treatment & 15 & 0.84 \\
Control & 15 & 0.64 \\
\hline
\end{tabular}

In the TABLE 3, appears that both groups of data are normally distributed.

TABLE 4. Mean cortisol level using parametric test ( $t$ test) in treatment and control group.

\begin{tabular}{lccc}
\hline \multicolumn{1}{c}{ Group } & Total $(\mathrm{N})$ & $\begin{array}{c}\text { Cortisol level } \\
(\mathrm{mg} / \mathrm{dL})\end{array}$ & $\mathrm{p}$ \\
\hline Treatment & 15 & $1.03 \pm 0.71$ & 0.00 \\
Control & 15 & $11.41 \pm 7.34$ & \\
\hline
\end{tabular}

From TABLE 4, we showed that cortisol level in treatment group is lower than the control group $(\mathrm{p}=0.00)$.

TABLE 5. Pain Score Data in Normality test result (Kolmogorov Smirnov) between treatment and control group

\begin{tabular}{lcc}
\hline Group & $\mathrm{N}$ & $\mathrm{p}$ \\
\hline Treatment & 15 & 0.10 \\
Control & 15 & 0.13 \\
\hline
\end{tabular}

From TABLE 5, we revealed that pain score in both groups are normally distributed.

TABLE 6. Different mean test using parametric test (t-test) between treatment and control group

\begin{tabular}{lccc}
\hline \multicolumn{1}{c}{ Group } & $\mathrm{N}$ & Pain Score & $\mathrm{P}$ \\
\hline Treatment & 15 & $4.46 \pm 0.83$ & 0.000 \\
Control & 15 & $7.34 \pm 0.74$ & \\
\hline
\end{tabular}

In the TABLE 6, it appears that pain scores were lower in treatment group compared with control $(\mathrm{p}=0.00)$ group.

\section{DISCUSSION}

Results of the data analysis showed significant differences on serum cortisol level in patients with advanced-stage cervical cancer after Cognitive Behavior Therapy (CBT) intervention which is lower than the standard therapy group. The meaning of it is the provision of Cognitive Behavior Therapy with standard therapy is more effective than just the standard therapy alone in patients with advanced-stage cervical cancer, so more likely to avoid the occurrence of depression, the impact of quality of life enhancement and allow an increasing in five year survival rate.

Advanced-stage cervical cancer is so stressful, whetherbiologically, psychologically and socially. Stress that occured can cause changes in psychoneuroimmunology which will have an impact on slow healing of cervical cancer patient. Improperly handled stress when it occured can cause interference regulation of the HPA axis, while this situation will stimulate the adrenal cortex to secretes cortisol, due to the increased production of ACTH from the anterior pituitary. ${ }^{7}$

Psychological stress will increases stress response, cause depression which impact to the HPA axis increased resulting in increased cortisol by the adrenal cortex. Biological stress can also cause an inflammatory reaction that affects the suppression of the immune system, then increase a secretion of pro-inflammatory cytokines (IL6, TNF $\alpha$ and IL-1), further can cause HPA axis dysregulation. ${ }^{8}$

This study is consistent with Schettler, ${ }^{9}$ he found that effort to reduce stress with psychotherapy CBT will have a positive impact on the life of human along with 
increasing of five-year survival rate of the patients. Cognitive Behavior Therapy is a psychotherapy based on cognition, assumptions, beliefs and behavior with the aim is influencing the disturbed emotion. The therapeutic uses of conditioning techniques to learn a new behavior, wherein the stimulus that cause anxiety switch to fun sensation and the application of these psychosocial methods, stress can be reduced so that the expected five year survival rate is increased. CBT emphasizes the importance role of mind, how we feel and what we do. ${ }^{10}$

Cortisol is known as the stress hormone, which is a steroid hormone produced by the adrenal glands, secreted through serial processes involving the HPA axis, which is a condition that is perceived as the pressure (stress). Those impulses are sent to the thalamus which then responded with the release of CRF (corticotropin-releasing factor) from the paraventricular nucleus in the hypothalamus. After that, CRF stimulates the pituitary gland to secrete ACTH (adreno corticotropin hormone). The presence of ACTH secretion lead to the secretion of glucocorticoids from the adrenal cortex. ${ }^{11}$ Role of Cognitive Behavior Therapy in the treatment of patients with advanced-stage cervical cancer, is expected can reduce the stress level in patient undergoing some treatment. It is a very positive impact, as it gives calmness which can reduce stress level in patients with advanced cervical cancer.

The analysis using Wong Baker Faces Pain Scale, in this study, showed a significant difference in pain score, decrease the pain score in treatment group compared to control group $(p<0.05)$. According to the International Association for the Study of Pain (IASP), pain is a sensoric and an unpleasant emotional experience, which accompanies tissue damage. Survey from Memorial Sloan-
Kettering Cancer Center showed that pain in cancer patient is usually a direct result of the tumor (75-80\% of cases) and the others are caused either due to anticancer treatment (15$19) \%$ ) and the pain unrelated to cancer or with treatment (3-5\%). Patients with cancer pain may experience acute pain, intermittent, or chronic at various stages in disease. Most of pain associated with cancer is considered as chronic pain. ${ }^{6}$

Pain in patients with advanced-stage cancer more often experienced as psychological symptoms, including depression and anxiety, than the general population. Advanced-stage patient, the disease does not go away, a history of mood disorders, or regimen of treatment that can lead to depression have a very high risk of depression that impact in the quality of life, including physical, psychological and social sustainability. Psychosocial aspects are lifestyle changes, fear, and psychosocial discomfort, including anxiety, anger, guilt, and depression. These things can settle down and change over time, depending on the severity of the disease. ${ }^{12}$

\section{CONCLUSION}

There is a significant difference in serum cortisol level and pain score in advancedstage cervical cancer, for them which given chemotherapy with CBT group has a lower cortisol level than the chemotherapy group without CBT.

\section{REFERENCES}

1. Rasjidi I. Epidemiologi Kanker Serviks. Indonesian Journal of Cancer 2009; 3(3):1038.

2. Nelson EL, Wenzel LB, Osann K, DoganAtes A, Chantana N, Reina-Patton A, et al. Stress, immunity, and cervical cancer: biobehavioral outcomes of a randomized 
clinical trial [corrected]. Clin Cancer Res 2008; 14(7):2111-8. http://dx.doi. org/10.1158/1078-0432.CCR-07-1632.

3. Limberaki E, Eleftheriou P, Gasparis1 G, Karalekos E, Kostoglou V, Petrou C. Cortisol levels and serum antioxidant status following chemoterapy. Healt 2011; 3(8):512-7. http:// dx.doi.org/10.4236/health.2011.38085.

4. Campbell CL, Campbell LC. A systemic review of cognitif behavioral intervention in advanced cancer. Patient Educ Couns 2012; 89(1):15-24. http://dx.doi.org/10.1016/j. pec.2012.06.019.

5. Berek, Jonathan S, Psychological Issues, Practical Gynecologic Oncology, Lippincott Williams \& Wilkins, Philadelphia 2005;86380

6. Schiff D, Wen PY, Cancer neurology in clinical practise, New York:Humana Press Inc 2003;57-70 https://doi.org/10.1007/978-1-59259-317-0

7. Cornah DF, Impact of Spirituality upon Mental Health. Mental Health Research Foundation. United Kingdom, 2006;(10)
8. Dalono. Mekanisme Psikoneuroimunologis Kejadian Ketuban Pecah Prematur (KPP) Karena Stressor Psikologis. [Disertasi] Surabaya: Universitas Airlangga; 2001.

9. Schettler T. The ecology of breast cancer: the promise of prevention and the hope for healing. Safer Chemicals, Healthy Families. 2013.

10. Young AH. Cortisol in mood disorders. Stress 2004; 7(4):205-8. https://doi.org/10.1080/10253890500069189

11. Talbott. Board review series obstetric and gynecology. $2^{\text {nd }}$ ed. Baltimore: Lippcot William \& Wilkins, 2011; 26-7.

12. Akechi T, Okuyama T, Onishi J, Morita T, Furukawa TA. Psychotherapy for depression among incurable cancer patients. Cochrane Database Syst Rev. 2008 Apr 16;(2) http://dx.doi.org/10.1002/14651858. CD005537.pub2. 